\title{
MENGENALKAN SISWA TENTANG PENTINGNYA BERINVESTASI DIMASA DEPAN PADA SISWA YAYASAN BINA MASYARAKAT INDONESIA
}

\author{
Amthy Suraya, Sugeng Widodo, Endang Suprapti, Suroto, Nani Rusnaeni \\ Universitas Pamulang \\ Email: dosen00627@unpam.ac.id
}

\begin{abstract}
Investments are important in order to prepare for the future by committing to an amount of money or other resources that is carried out now with the expectation of a higher return or benefit in the future. The purpose of this training is to instill an understanding of the importance of investing from an early age, the forms of investment and application or investment practices in everyday life. The training technique uses lectures, practices and demonstrations by involving participants to be active in question and answer and educational games. The results of this activity are expected that students and students of MTS Mathlaul Anwar can have knowledge and awareness of investment, reduce and even avoid harmful consumptive behavior and can start investing from simple and possible things in everyday life.
\end{abstract}

Keywords: Investment Knowledge, Students, Future.

\begin{abstract}
Abstrak
Investasi merupakan hal penting dalam rangka mempersiapkan masa depan dengan cara berkomitmen atas sejumlah uang atau sumber daya lainnya yang dilakukan saat ini dnegan harapan adanya pengembalian atau manfaat yang lebih tinggi nilainya di keudian hari. Tujuan pelatihan ini adalah untuk menanamkan pemahaman pentingnya investasi yang dilakukan sejak dini, bentuk bentuk investasi dan aplikasi atau praktek investasi dalam kehidupan sehari hari. Teknik pelatihan dengan metode ceramah, praktek dan demonstrasi dengan melibatkan peserta untuk aktif dalam tanya jawab dan permainan edukatif. Hasil kegiatan ini diharapkan bahwa siswa dan siswi MTS Mathlaul Anwar dapat memiliki pengetahuan dan kesadaran akan investasi, mengurangi bahkan menghindari perilaku konsumtif yang merugikan serta dapat memulai melakukan investasi dari hal hal yang sederhana dan memungkinkan pada kehidupan sehari hari.
\end{abstract}

Kata Kunci: Pengetahuan Investasi, Siswa, Masa Depan.

\section{A. PENDAHULUAN}

Konsumsi yang dilakukan oleh seseorang layaknya berdasarkan kebutuhan dasar, namun perilaku masayarakat Indonesia saat ini cenderung konsumtif. Hal ini tidak hanya terjadi pada orang dewasa saja, namun juga sudah masuk kepada generasi generasi remaja, 
dimana saat ini kondisi berbelanja sangatlah mudah dengan adanya kemudahan pada belanja online, lebih jauh perilaku konsumtif ini dapat mengakibatkan kecanduan belanja atau shopaholic yang tentunya ini buruk bagi anak anak remaja, karena mereka adalah bibit penerus bangsa.

Berdasarkan data BPS (2019) Indeks Tendensi Bisnis (ITB) Indonesia lebih rendah dibandingkan dengan Indeks tendensi Konsumen (ITK). Indeks Tendensi Bisnis (ITB) pada triwulan I-2019 sebesar 102,10 hal ini menunjukkan bahwa kondisi bisnis secara umum terus bertumbuh, namun optimism pelaku bisnis ternyata lebih rendah dibandingkan dengan triwulan tahun sebelum nya pad triwulan IV yaitu sebesar 104,71. Indeks Tendensi Konsumen (ITK) pada triwulan IV -2018 sebesar 110, 54, menurun 5,59\% pada triwulan I2019 menjadi 104,35. Walaupun menurun, karena posisi ITK $>100$ maka hal ini menunjukkan masyarakat Indonesia tinggi nilai konsumsinya. Wilayah tertinggi yaitu Provinsi banten sebesar 117,97 pada triwulan I-2019. Tangerang Selatan yang merupakan salah satu kota di Wilayah banten otomatis memberikan sumbangsih atas nilai tersebut.

Data rata rata pengeluaran per kapita Sebulan Menurut kelompok Komoditas dan kelompok Keluaran di Tangerang Selatan (BPS tangselkota, 2019) posisi tertinggi pada pengeluaran perumahan dan fasilitas rumah tangga sebesar Rp 676.126 perbulan dan posisi kedua yaitu pengeluaran untuk makanan dan minuman jadi sebesar Rp 338.269, dan posisi ketiga yaitu aneka barang dan jasa sebesar Rp 313.498 sebulan. Dengan Jumlah pendududk Tangerang Selatan berdasarkan data BPS per 2017 sebesar 1.298.504 jiwa,hitungan di atas menjadi sangat tinggi nilainya. Sebesar 14,70 persen merupakan penduduk dengan kategori usia 10-19 tahun. Dimana usia ini merupakan usia remaja yang mulai senang berksplorasi mencoba hal hal baru termasuk dengan fashion atau makanan.

Fenomena diatas menjadi bahan pertimbangan bagi pemerintah dalam membuat kebijakan pendidikan dan pengawasan orangtua dalam mendidik putra putri yang berusia remaja. Sehingga pengenalan investasi dan pemahaman mendalam dalam berinvestasis sudah menjadi kebutuhan untuk disampaikan sejak dini kepada generasi remaja saat ini, baik pengetahuan akan bentuk investasi finansial dan investasi investasi lainnya. Berdasarkan permasalahan tingkat konsumtif yang tinggi dan kekhawatiran akan perilaku konsumtif di kalangan remaja, maka pengabdian kepada masyarakat (PKM) ini mengambil Tema "Mengenalkan pentingnya berinvestasi di masa depan pada siswa yayasan bina masyarakat Indonesia".

\section{B. METODE PELAKSANAAN}

Khalayak sasaran dalam kegiatan pengabdian pada masyarakat ini adalah siswa Yayasan Bina Masyarakat Indonesia. Kegiatan Pengabdian pada masyarakat ini dilaksanakan pada tanggal 04 Juni - 06 Juni 2020. Rencana kegiatan yang akan dilakukan untuk menyukseskan kegiatan pengabdian ini, yaitu:

1. Peralatan yang dibutuhkan untuk melaksanan kegiatan ini. Pada tahapan ini pelaksana memulai dengan melakukan koordinasi dengan instansi terkait.

2. Penentuan Lokasi. Pada tahap ini dilakukan kunjungan ke lokasi untuk menentukan tempat (lokasi). Dalam memilih lokasi, kami mempertimbangkan dengan jarak yang kami tempuh dari Universitas ke lokasi pengabdian.

3. Perancangan kebutuhan. Adapun tahapan yang dilakukan dalam perancangan kebutuhan secara berurutan adalah sebagai berikut:

a. Perancangan materi dampak bahaya konsumsi berlebihan bagi siswa.

b. Perancangan materi tentang upaya menumbuhkan jiwa investasi bagi siswa.

4. Perancangan alat. Perancangan alat yang dibutuhkan sebagai berikut: 
a. Menyiapkan sound system.

b. Menyiapkan proyektor.

\section{HASIL DAN PEMBAHASAN}

Keputusan dalam mengambil investasi sesorang menurut Sharpe (2005) dilatarbelakangi oleh pemahaman akan investasi. Pemahan investasi ini meliputi pengetahuan dari jenis-jenis investasi, return yang akan diperoleh, risiko yang dihadapi, cara analisis, hingga hal-hal lain yang terkait dengan psikologis. Pengetahuan investasi ini dapat diperoleh darimana saja, mulai dari Pendidikan formal seperti di perguruan tinggi atau pendidikan non formal seperti pelatihan,

Pengetahuan tentang investasi ini akan mengarahkan calon investor dalam jenisjenis investasi terbaik yang akan dipilih. Pengetahuan dasar yang harus diketahui oleh seorang calon investor sebelum melakukan investasi ialah seberapa besar return yang akan diperoleh dari produk investasi yang dipilih, besarnya risiko yang akan ditanggung. Return merupakan pertimbangan awal yang harus diambil investor sebelum memulai menanamkan modalnya kedalam investasi. Investasi yang ditananmkan bertujuan untuk memperoleh peningkatan keuntungan yang dapat dirasakan atau dinikmati di masa yang akan datang.

Maka dengan demikian, seorang investor yang baik tentu akan merencanakan dan memperhitungkan besarnya return yang akan diterima. Sejalan dengan hal tersebut, Robert (1995) tanpa adanya return yang dapat diperoleh dari suatu produk investasi, tentunya investor tidak akan menananamkan modalnya pada produk investasi tersebut.

Pada investasi pasar modal, return dan risiko memiliki hubungan yang positif. Semakin tinggi return yang akan diperoleh investor dalam investasi maka risikonya pun semakin tinggi, sehingga investor berpotensi besar mengalami kerugian bahkan kehilangan modalnya. Tingginya return dalam investasi tidak menjamin bahwa investor akan mengambil produk investasi tersebut jika modal minimal dan risikonya terlalu besar, terutama bagi kalangan kalangan ekonomi menengah kebawah ataupun bagi mahasiswa. Oleh karena itu diperlukan analisis yang cermat sehingga pengetahuan investasi yang memadai sangat dibutuhkan untuk mengambil sebuah keputusan berinvestasi.

Dalam mempertimabangkan risiko dalam investasi, Sjahrial (2014) mengemukakan bahwa terdapat beberapa factor yaitu ketepatan proyeksi aliran kas yang dipengaruhi oleh estimasi penjualan, mengevaluasi kelayakan investasi dan memperhatikan ada tidaknya hambatan untuk masuk dab keluar dalam industry.

Orang lebih cenderung membeli suatu barang apabila barang tersebut dinilai memiliki manfaat lebih terutama dalam hal finansial atau produk investasi. Pada umumnya seseorang akan membeli produk investasi setelah ia mengetahui apa saja manfaat yang bisa diperoleh dari produk investasi tersebut serta bagaimana prosedur investasi menghasilkan keuntungan. Kenyataan yang terjadi di lapangan adalah banyak investor yang membeli produk investasi hanya berdasarkan informasi/ pengetahuan tentang keuntungan return yang akan diperolehnya tanpa ia mengetahui resiko yang akan ditanggung. Hasilnya betapa banyak kasus penipuan berbasis pada produk investasi terjadi yang mengakibatkan kerugian yang besar kepada pada investor dan membuat calon investor baru kehilangan minat untuk menginvestasikan dananya. Oleh karena itu, pentingnya pengetahuan akan produk investasi yang di miliki seseoarang akan berdampak kepada minat untuk membeli atau tidak pada produk investasi. 


\section{KESIMPULAN DAN SARAN}

\section{Kesimpulan}

Dalam melakukan keputusan investasi, diperlukan pemahaman yang baik tentang investasi dan memilih investasi terbaik dengan perkiraan mendapatkan pengembalian atau keuntungan yang tinggi, risiko yang akan dihadapi, serta berlandaskan kebutuhan konsumen.

Investasi juga lebih mudah apabila sesuai dengan kesenangan, pekerjaan, hobi dan lainnya, sehingga seseorang bergerak mewujudkan keingina atau minat tersebut.

\section{Saran}

Disarankan kepada tenaga pengajar dan akademisi untuk lebih memperluas jangkauan dalam menyebarluaskan informasi kepada siswa siswi di wilayah Tangerang Selatan sehingga masyarakat luas dapat merasakan manfaat dari kegiatan PKM yang diadakan oleh akademisi di lingkungan Prodi manajemen.

\section{DAFTAR PUSTAKA}

Dumilah, R., Sunarto A., Ahyani, Solihin, D., Maulida H. (2020). Pelatihan Pemanfaatan Media Sosial Untuk Promosi Usaha Atau Bisnis Bagi Siswa. DEDIKASI PKM. Vol. 1. No. 1.

Jogiyanto. (2016). Teori Portofolio dan Analisis Investasi. Edisi 10. BPFE. Yogyakarta.

Sjahrial, Dermawan. (2014), Manajemen Keuangan Lanjutan. Jakarta: Mitra Wacana Media

Sukirno, S. (2012). Makro Ekonomi Teori Pengantar (3rd ed). Jakarta: Raja Grafindo Persada.

Tandelilin, Eduardus. (2010). Portofolio dan Investasi: Teori dan Aplikasi. Edisi 1. Kanisius. Yogyakarta. 